\title{
Mechanical Dilatation of the Lower Esophageal Sphincter and a Novel Surgical Concept for Treatment of Achalasia
}

\author{
Johannes Lenglinger Enrico P. Cosentini Martin Riegler \\ University Clinic of Surgery, Department of General Surgery, Medical University of Vienna, Austria
}

\section{Dear Editor}

With interest we read the article by Abir et al. [1] entitled 'Surgical treatment of achalasia: Current status and controversies' including a brilliant overview on pharmacologic, interventional and surgical treatment modalities. However, we would like to point out the following considerations on the topic: (1) In our institution we use the 'Starck dilator', a mechanical device with four expandable metal branches allowing a maximal diameter of up to $4 \mathrm{~cm}$. Using the Starck dilator we obtain similar success rates without perforation [2], when compared to up to $15 \%$ as reported for pneumatic dilatation [1]. This may at least in part be due to a more uniformed application of mechanical force directed towards the circumference of the esophagogastric junction via the four expandable metal branches of this mechanical dilator [3]. In addition, the Starck dilator is considered to allow direct transmission of tissue resistance to the handset via the metal branches when compared to an air-filled balloon used during pneumatic dilatation, thus indicating successful dilatation of the lower esophageal sphincter. (2) Concerning the surgical treatment of achalasia, we would like to bring to your attention a novel concept including transgastric stapled esophagofundostomy (TSE) and partial fundoplication [4]. In contrast to myotomy [1], TSE results in complete dissection of the left lateral wall of the distal esophagus and the esophagogastric junction, thus suggested to disenable closure of the myotomy. Although still at an experimental level, TSE is suggested to evolve suitable for individuals with end-stage achalasia with or without unsuccessful prior dilatation(s) [5]. The transgastric approach is considered to be advantageous in patients following failed myotomy, where $a b$ externis identification of the musculature covering the esophagogastric junction may be difficult or impossible [6]. (3) In results of the abstract, the authors include balloon dilatation into medical therapy. To our understanding, the term interventional therapy would seem more suitable for dilatation.

\section{References}

1 Abir F, Modlin I, Bell R: Surgical treatment of achalasia: Current status and controversies. Dig Surg 2004;21:165-176.

-2 Pratschner T, Schiessel R, Stacher M, Feil W, Schemper M: Dilatation treatment of achalasia as initial therapy. Results of a prospective study. Wien Klin Wochenschr 1996;108:191195.

-3 Cosentini EP, Wenzl E, Jakesz R: Treatment of achalasia. Wien Klin Wochenschr 2004;116: 296-304.

-4 Cosentini E, Riegler M, Koperek O, Wenzl E: Transgastric stapled esophagofundostomy (TSE) and partial fundoplication - A technical illustration of a new concept for surgical treatment of achalasia. Eur Surg 2004;36:89-94.

-5 Bremner CG: Invited commentary to 'Transgastric stapled esophagofundostomy (TSE) and partial fundoplication - A technical illustration of a new concept for surgical treatment of achalasia'. Eur Surg 2004;36:95-96.

- 6 Junginger T, Gockel I: Invited commentary to 'Transgastric stapled esophagofundostomy (TSE) and partial fundoplication - A technical illustration of a new concept for surgical treatment of achalasia'. Eur Surg 2004;36:203-204.

\section{KARGER}

Fax +41613061234

E-Mail karger@karger.ch

www. karger.com
(C) 2005 S. Karger AG, Basel

0253-4886/05/0223-0203\$22.00/0

Accessible online at:

www. karger.com/dsu
Johannes Lenglinger, MD

University Clinic of Surgery, Department of General Surgery

Medical University of Vienna, Währinger Gürtel 18-20

AT-1090 Vienna (Austria)

Tel. +43 140400 5621, E-Mail franz.riegler@meduniwien.ac.at 